
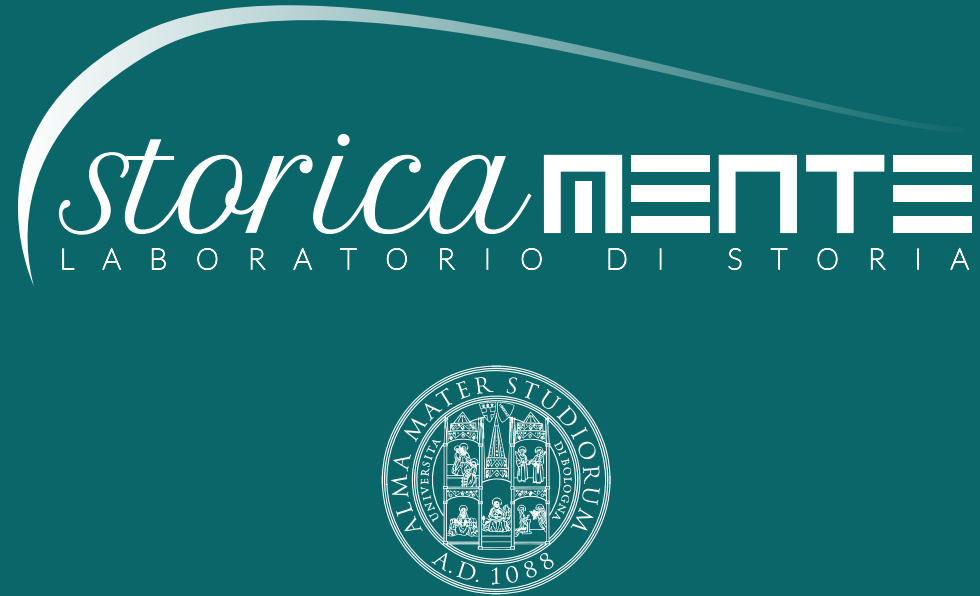

ALMA MATER STUDIORUM

Università di Bologna

Dipartimento di Storia Culture Civiltà

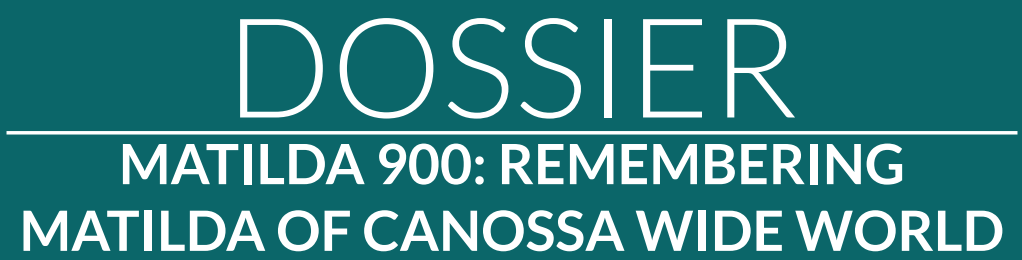




\section{STORICAMENTE.ORG}

\section{Laboratorio di Storia}

Francesca Guerri

Nihil Terrenum, Nihilque Carnale in Ea: Matilda of Tuscany and Anselm of Lucca during the Investiture Controversy

Numero 13 - 2017

ISSN: $1825-411 \mathrm{X}$

Art. 31

pp. 1-37

DOI: $10.12977 /$ stor684

Editore: BraDypUS

Data di pubblicazione: 03/01/2018

Sezione: Dossier: "Matilda 900: Remembering Matilda of Canossa Wide World" 


\title{
Nihil Terrenum, Nihilque Carnale in Ea: Matilda of Tuscany and Anselm of Lucca during the Investiture Controversy
}

\author{
FRANCESCA GUERRI \\ University of Houston, History Department
}

This article investigates the relationship between Matilda of Tuscany and her spiritual advisor Anselm of Lucca during the tumultuous period of the Investiture Controversy. The contemporary sources - two Vitae of Anselm of Lucca and Donizo's Vita Matildis - highlight both the spiritual and the secular dimension of this friendship. Furthermore, the bishop of Lucca's five Prayers written for the countess uncover a new aspect of Anselm and Matilda's relationship. In these texts Anselm, while expressing a novel devotion to Christ and to the Virgin Mary, shows the origin and goal of his fatherly direction for Matilda. Anselm's novel devotion seems to have been triggered by the life and mission of Countess Matilda, generated by their common obedience to Gregory VII, and influenced by the Eucharistic Controversy, with which Anselm was associated.

\section{Introduction}

"As Jesus dying on the cross had entrusted his mother to his disciple John, thus Pope Gregory [VII] entrusted the lady, Countess Matilda [of Tuscany] to Anselm [of Lucca]».' Of the countless people recorded

Vita Mathildis, 2, vv. 284-286, 385. Unless otherwise noted all translations are my own. 
in Donizo's Vita Mathildis, Anselm of Lucca ranks as one of the most significant. He was not only the friend but also the spiritual advisor of the countess during the tumultuous period of the Investiture Controversy. The contemporary sources - two Vitae of Anselm of Lucca and Donizo's Vita Matildis ${ }^{2}$ - highlight both the spiritual and the secular dimensions of this friendship. Furthermore, the bishop of Lucca's five Prayers written for the countess reveal various aspects of Anselm and Matilda's relationship. In these texts Anselm, while expressing a novel devotion to Christ and to the Virgin Mary, ${ }^{3}$ shows the goal and origin of his fatherly direction for Matilda. But what was Matilda's political, spiritual, and ideological program, and how was it influenced by Anselm's spiritual guidance? Were the Prayers designed specially for Matilda's personality and needs? What was it that enabled Anselm to develop these new ideas? In order to answer these questions, it is essential to investigate the bishop of Lucca's education and background and to read his Prayers and the other aforementioned sources against the larger cultural setting, involving not only the Gregorian but also the Anglo-Norman tradition. I argue that the comparison between the Virgin Mary and Matilda developed by the two Vitae and by Donizo was encouraged by Anselm himself and first articulated in his Prayers; at the same time, Anselm's novel devotion seems to have been triggered by the life and mission of Countess Matilda, generated in the obedience to Gregory VII, and influenced by the Eucharistic Controversy, with which Anselm was associated.

The relationship between Anselm and Matilda began and developed during the critical period of open conflict between Emperor Henry IV and Pope Gregory VII (1076-1086). The evidence for their relationship is scattered in various sources. The first Vita Anselmi episcopi Lucensis was commissioned by Matilda and written anonymously in 
prose one year after Anselm's death in 1086. ${ }^{4}$ The writer's aims were both to describe Anselm as a strenuous defender of reform and to obtain his canonization. ${ }^{5}$ For the same reasons, Rangerius, bishop of Lucca after Anselm (1087-1112) dedicated to Matilda Vita metrica sancti Anselmi Lucensis episcopis, written in verse, probably between 1096 and 1099 [Saverino 1992, 223-272; Amari 2015]. Rangerius follows the previous Vita, even though he expands and enriches it with new facts [Cushing 1998, 3-4]. Finally, the countess's biographer, Donizo, wrote Vita Mathildis between 1112 and 1115. The illuminated manuscript, written in leonine hexameter, provides a moralizing description of the life of the countess and her ancestors. Donizo recounts the achievements of the Canossa dynasty and praises the countess as being responsible for the survival of the reforming ideas [Golinelli 2008]. A more personal and emotional tone emerges in Anselm's five Prayers written for Matilda, ${ }^{6}$ and in a passage of Anselm's Book against Wibert. ${ }^{7}$ It is important to analyze these sources taking into account the broader cultural setting in which Matilda and Anselm lived, in order to comprehend their motivations and contribution to the events of their time.

\section{Matilda and her family}

To better understand the relationship between the pope's canonist and the grand countess, it is essential to look at the background of Matilda's

For more details regarding this work see: Pasztor 1960, 1-33; 1992, 207-222; Golinelli 1987, 16-26; 1988, 118-155.

For the structure of this work see Golinelli 1988, 117-155.

Anselm II of Lucca, Prayers, in Wilmart 1938.

Anselm II of Lucca, Liber contra Wibertum. 
family, especially its political and religious tradition. ${ }^{8}$ Countess Matilda of Tuscany (1046-1115) was the daughter of Boniface of Tuscany and Beatrice of Lorraine. Her mother was the daughter of Matilda of Swabia, sister of Empress Gisela, and Frederick II, duke of Upper Lorraine [Bartolini 1965]. Emperor Henry III and Henry IV were Matilda's first and second cousins [Golinelli 2007, 84-94]. ${ }^{9}$ Her father was the heir to the great Canossa dynasty, celebrated by Donizo in his poem dedicated to Matilda.

The fortunes of Atto of Canossa, the progenitor of the family, began with his loyalty to Emperor Otto I of Germany, an alliance that allowed Atto to extend and enhance his power. Indeed, Atto's acquisition of the title of count over three territories - Reggio Emilia, Modena, and Mantua (January 962) - coincided with the rise of the emperor's power in Italy in 961 [Fumagalli 1971, 74-77]. ${ }^{10}$ Atto's son, Tedaldo, supported the rise of Emperor Henry II of Germany and by this means acquired Ferrara and founded the monastery of Polirone in Mantua [Golinelli 2007, 50-56]." Tedaldo's son, Boniface, Matilda's father, continued the tradition of the family and received the title of duke of Tuscany from Emperor Conrad II. With Boniface, the centers of the Canossa's territory became Mantua and the monastery of Polirone [Golinelli 2007, 65-69; Bartolini 1970, 108].

The partnership between the Canossa family and the papacy became an important feature of this powerful dynasty, thanks to the religious conviction of Matilda's mother. Indeed, through Beatrice, Boniface became close to the key figures of the new ecclesiastical reforming par-

For more details about the life of Matilda of Tuscany see: Golinelli 2015; 2009; 2007; Fumagalli 1996; Duff 1909; Huddy 1906; Tosti 1859.

Vita Mathildis, 1, vv. 781-794, 367; vv. 1140-1206; 374-376.

10 For the origins of the Canossa family see: Robinson 2004, 48-49; Golinelli 2008 IX-XVI, 241-251; 2007, 19-64; Sergi G. 1994, 29-40; Fumagalli 1971.

11 Ibidem vv. 439-443, 361. 
ty: Pope Leo IX, Peter Damian, Humbert of Silva Candida, and Guido of Pomposa [Golinelli 2007, 32-36; Fumagalli 1999, 15-18; D'Acunto 1999, 298-305]. In this period the pope, together with the papal reform movement, was close to Emperor Henry III, who was considered an important ally in the advancement of the ideals of the reform against simony and clerical marriage. Likewise, his power was needed in order to free the Church from the threat of the aristocratic Roman families, who used to manipulate the election of the popes in their favor [Cowdrey 1998, 1-37]. The harmony between the empire and the Canossa lineage was upset when Boniface died in 1052, and after two years Beatrice married Godfrey the Bearded, duke of Upper Lorraine, without the emperor's knowledge. The powerful duke was an enemy of Henry III who promptly imprisoned Beatrice in Germany; she would be released only at the death of Henry III [D'Acunto 1999, 305]. The emperor's young son, Henry IV, was unable to provide assistance and protection to the Church, and for this reason, the reforming party was forced to pursue new supporters, and Godfrey of Lorraine was perfectly fit for this task. This change in the political alignments of the German empire favored the Canossa-Lorraine lineage, which became the most tireless protector and ally of the papacy [Golinelli 1991, 199; Lazzari 2012]. It is not by chance that the reformed popes, Stephen IX (1057-1058), Nicholas (1058-1061), and Pope Alexander II (1061-1073), were all tied to the new margrave of Tuscany, owing their election to this connection [Cowdrey 1998, 37-59; Robinson 2004, 4-5, 10]. At Godfrey the Bearded's death, Beatrice replaced her husband as margrave of $\mathrm{Tu}$ scany, and under her jurisdiction, the connection between the papacy and the powerful dynasty became stronger [Robinson 2004, 10-17; Golinelli 2007, 151-157].

Between 1069 and 1073, although they still sought the approval of the emperor, Beatrice and Matilda fostered the advancement of the ideals of the reform movement. Matilda and Beatrice were both vassals of the German emperor and related to him by blood but at the same time, 
they were close to the reform movement and the papacy. Beatrice and Matilda served as prudent mediators, mainly during the first years of the conflict between young Emperor Henry IV and Pope Gregory VII, a role that was facilitated by the strategic location of their domains in central Italy [Golinelli 1991, 195-206]. For example, the newly elected pope asked them to work, together with Empress Agnes, to persuade the emperor to remove the excommunicated counselors from his courts and make peace with Rome.12 Beatrice and Matilda also mediated on behalf of the papacy, in the ongoing conflict between the Pataria and the archbishop of Milan [Robinson 2004, 14-15; Golinelli 2007, 151-157].

\section{Anselm and his background}

The strong alliance between the reform papacy and the Canossa-Lorraine family would connect Matilda and Anselm II, bishop of Lucca (1040-1086). Certainly, Beatrice and Godfrey the Bearded became close to his uncle, Anselm I of Lucca - later Pope Alexander II - when they supported his struggle for the chair of St. Peter, which had been challenged by the antipope Cadalus of Parma, the appointee of the imperial court [Cowdrey 1998, 49-53]..13 The details of Anselm's early life, his family, and his education are mostly unknown; the few known facts are disseminated in various sources. Born in Milan in 1040, his family was part of the city's nobility. ${ }^{14}$ It was probably his illustrious

For the relationship between Matilda and Pope Gregory VII and Matilda's role of mediator between pope and emperor see: Golinelli 1991; also, Gregory VII's Registrum, in Cowdrey 2002.

13 Bonizo of Sutri, Book to a Friend, in Robinson 2004, 196-219.

14 Vita Metrica, vv. 1-12, 1157; Violante 1961; Cushing 1998, 43-44, Keller 1992, 29-34; For more details on Anselm's life see: Rota, 1773; Pasztor 1960; 1964; 1987; 1992; Golinelli 1987; Violante 1992; Cushing 1998; Brunelli 2008. 
uncle who took responsibility for Anselm's education, directing him, at first, toward the Cathedral of Milan, ${ }^{15}$ where he studied grammar and dialectic. ${ }^{16}$ The subsequent progress of Anselm's education is hard to pinpoint, and is a subject of discussions among scholars. However, his path and career probably followed the pattern of many northern Italian scholars of the eleventh century, like Lanfranc of Pavia and Anselm of Aosta, who, as Cowdrey argues, began their educations in Milan and then involved «travel to distant lands», in order to continue their study or find a vocation that would have been difficult to find in Italy [Cowdrey 1972, 115]. Kathleen Cushing argues: "Any attempt to understand the world in which Anselm grew to maturity is caught up in the larger problem of determining what precisely was occurring in northern Italy, especially in terms of intellectual developments».

The first evidence connecting Anselm to Normandy and Bec is the fact that his uncle, Pope Alexander II, had himself been Lanfranc's pupil and that they worked closely and harmoniously during their lifetimes [Cushing 1998, 46-48; Cowdrey 2003, 21-23; Vaughn, Rubenstein, 2006, 341]. There are also some suggestions that Anselm II himself could have been Lanfranc's student; however, the sources are not conclusive on this matter. ${ }^{18}$ We also know that Anselm had been in contact with William I of England, through a letter that he wrote to the king in 1085 asking for military support for the Church and Gregory VII. In this letter Anselm refers to the presumed help that the Norman king had repeatedly provided him in the past: «However, I am mindful of the benefits that your benevolence had bestowed on me». ${ }^{19}$ Despite this

Vita Anselmi, c. 74, 33; Violante 1961; Cushing 1998, 43-44.

16 Vita Anselmi, c. 2, 13.

17 Cushing 1998, 45.

18 For this debate see: Borino 1956, 361-374; Keller 1992, 27-50; Cushing 1998, 45-48; Cowdrey 2003, 19-24.

19 Anselm II of Lucca, letter to William I of England, 1085. 
evidence, the exact link between Anselm II and the Norman world is hard to nail down; however, from an investigation of the bishop of Lucca's work and the few sources for his life, it would seem likely that Anselm was in contact with the new intellectual ideas developed at Bec by Lanfranc and by Anselm of Canterbury.

Anselm's career as a Gregorian bishop began when his uncle, Pope Alexander II, nominated him as his successor in the bishopric of Lucca in 1073. ${ }^{20}$ This city was the capital of the domains of Beatrice and Matilda, and as such played a pivotal role in the exercise of their power. They therefore felt an urgency to place a loyal bishop in the seat of Lucca and pressed the new pope, Gregory VII, to appoint Anselm. ${ }^{21}$ When the pope and the emperor reconciled at the beginning of 1074, Anselm received permission from Rome to accept the investiture from the hands of the emperor. ${ }^{22} \mathrm{He}$ was consecrated by the pope in September 1074, but soon thereafter, Gregory VII prohibited lay investitures during the Lenten Synod of 1075. Subsequently, in May of the same year, Anselm regretted his imperial obedience and decided to withdraw from the world to the abbey of St. Gilles. The peace of the contemplative life, for which he had yearned, did not last long. At the end of 1075, Gregory recalled him and consecrated him, ex novo, bishop and monk. ${ }^{23}$ At the beginning of 1076, he returned to his episcopal see in Lucca. Both Vitae emphasize Anselm's unconditional obedience to Pope Gregory VII.

For Anselm's career see also: Violante 1992; Golinelli 1987; Pasztor 1960; 1992; Cushing 1998, 55-63. Regarding Anselm's investiture see: Vita Anselmi, cc. 3-9, 1415; Vita Metrica, 1176-1179; Violante 1961; Fiorentini 1756, 140; Cushing 1998, 48 55; Gregory VII, Registrum, I, 21, in Cowdrey 2002, 25-26; Violante 1961.

${ }_{21}$ Gregory VII, Registrum 1, 11, in Cowdrey 2002, 11-12.

${ }^{22}$ Vita Anselmi, c. 3, 14; Cushing 1998, 49-52.

${ }_{23}$ Vita Metrica, vv. 1443-1446, 1187. 


\section{Pope Gregory VII, Countess Matilda, and Anselm during the Investiture Controversy}

This obedience held the countess and the new bishop together through the most critical moment of the war between Henry IV and Gregory, which began with Gregory's unexpected excommunication and deposition of the emperor in 1076. ${ }^{24}$ In the same year, Matilda's mother and her husband died, and the countess inherited a vast domain stretching from the region of Latium to northern Italy, which she ruled in her own right. The pope's significant change of direction in the history of church reform led to a total rupture in his relationship with Henry and compelled Matilda to abandon her role as mediator; she embraced entirely the cause of the reforming party, thus departing from the political tradition of her family. During this difficult time, Matilda didn't act in isolation; on the contrary, she was assisted by her spiritual director Anselm II, who was entrusted to her by Gregory VII [Golinelli 1991, 205; 2007, 232-239; Wilmart 1938, 23-48].

Indeed, after the reconciliation of Canossa in 1077, Anselm became a man of crucial importance in the development of the ideals of the reform and a vigorous ally of the pope; it was in this period that he was appointed permanent legate of the Holy See in Lombardy [Cushing 1998, 44-63]. At the same time, Anselm, as bishop of Lucca, tried to impose the practices of chastity, communal life, and renunciation of personal property on the secular clergy of the city. ${ }^{25}$

Gregory fully supported Anselm and his mission, and he went to Lucca in 1076 to exhort the canons to obey their bishop; in 1077-1078 he reproached the clergy for not obeying the papal strictures, and excommunicated them in 1079 for plotting against Anselm and for their persistent disobedience. Likewise, Matilda was working with the bishop

Simeoni 1947, 353-372.

For more details on this subject see: Pasztor 1987; Cushing 1998, 43-63; Golinelli 2007, 232-239; Puglia 2013, III-21. 
of Lucca in his effort to reform his diocese. To accomplish this intent, between 1077 and 1080 the bishop attempted to reorganize the bishopric and to reacquire its property that had previously been usurped by the episcopal tenants. ${ }^{26} \mathrm{He}$ received from Matilda numerous territories plus military and moral assistance. ${ }^{27}$ Even though Matilda used her army and her spiritual authority to ensure the success of Anselm's mission, the bishop of Lucca's project to reform the canons ended in failure. Moreover, the year 1080 proved to be extremely difficult for both Matilda and the papal party. In March Gregory excommunicated Henry IV for the second time, and the king promptly responded by electing the anti-pope Clement III, the bishop of Ravenna, Wibert. These dramatic events followed the famous battle of Volta Mantovana in 1080, in which the troops of the schismatic bishops in northern Italy defeated Matilda's army. ${ }^{28}$ At the same time, in Germany, the anti-king Rudolf of Swabia - elected by Henry's enemies and an ally of the pope - died in the notorious battle on the Elster River. Henry entered Lucca on July 25th, 1081, and while granting its citizens numerous privileges, declared Countess Matilda guilty of high treason and confiscated all her domains. The canons, allied with the troops of the new anti-pope Clement III, defeated the countess and exiled Anselm, who took refuge with Matilda's entourage. The other cities of Tuscany and the Lombard vassals followed Lucca's example and rebelled against the countess. Numerous contemporary sources identify Anselm as the most diligent imitator of Gregory VII. An important evidence of this discipleship can be found in the Collectio Canonum, written by Anselm at the behest of the pope and conceived as the official defense of the Gregorian arguments concerning the relationship between regnum and sacerdotium.

On this matter see: Spicciani 1992, 65-112; Fonseca 1992, 51-64; Cushing 1998, 58-61.

27 Vita Anselmi, cc. 6-10, 15-16; Vita metrica, vv. 1443-1763, 1187-1193.

28 Ghirardini 1987, 229-240; Eads 2000, 129. 
Inspired by the holy fathers of the Church, Anselm defended the power and the primacy of the pope over the whole of Christendom; accordingly, he stressed the concept of obedience, a duty owed by the faithful, from which unity depended. Anselm's conclusion foresaw de iusta vindicta; i.e., the severe persecution and correction of disobedience, which became the moral justification for the use of violence and war in religious controversies. The concepts laid out by Anselm were the cornerstone of the Gregorian ideals. ${ }^{29}$

\section{Matilda and the Virgin Mary}

In the sources I examined, Matilda is described as the bride of Christ, and her life is compared to Mary's. Ropa and Golinelli have analyzed this crucial comparison in great depth, and their valuable arguments were crucial for my research. They focused mainly on Anselm's and Matilda's official biographers to examine this comparison. My investigation, while paying due attention to the work of the biographers, relates these Marian images to the content of Anselm's Prayers. For the analysis of the Prayers I drew mainly from the works of Cantelli and Fulton, whose important studies focused primarily on Anselm and identified him as a great innovator in the tradition of Marian devotion and doctrine. However, they did not look into the origin of Anselm's innovation and the role of Matilda in this accomplishment. By analyzing the aforementioned sources, together with the larger background of both the Gregorian and the Anglo-Norman worlds, I argue that this comparison between Mary and Matilda was inspired by Anselm and first expressed in his Prayers; Anselm's novel devotion seems to have been triggered by the life and mission of Countess Matilda, generated by

For more details on the Collectio Canonum see: Stickler 1947, 235-285; Pasztor 1964, 91-115; Robinson 2004, 354; Cushing 1998, 43-142. 
their common obedience to Gregory VII and influenced by Anselm's involvement with the Eucharistic Controversy.

As we have seen, the close relationship between Anselm and Matilda began and developed during the critical period of open conflict between Emperor Henry IV and Pope Gregory VII (1076). As Paolo Golinelli has argued, it was probably at this critical moment, in which Matilda found herself alone after the loss of both her mother and her husband, that Gregory entrusted her to the care of Anselm. According to Vita Anselmi:

And so that [Matilda], alone, would not succumb she was entrusted to the spiritual and charitable care of the aforementioned bishop of Lucca, Anselm: a most faithful disciple to a most trustworthy teacher, as when Jesus on the cross entrusted his virgin mother to his virgin disciple, saying: "Woman, behold, your son!" and to the disciple, "Behold, your mother". ${ }^{30}$

Likewise, Donizo says: «[...] As Jesus dying on the cross had entrusted his mother to his disciple John, Pope Gregory [VII] entrusted the lady, Countess Matilda to Anselm [of Lucca]».31 This passage referring to the Gospel of John [1:27] introduces a key aspect of the relationship between Anselm and Matilda and can be read on various levels. The direct parallels between Jesus and Gregory VII, Mary and Matilda, and John and Anselm is crucial [Golinelli 1987, 48]. In obeying Gregory VII, Matilda and Anselm obey Jesus himself. Matilda is compared to the Virgin Mary, mother of Jesus, mother of the Church, and mother

\footnotetext{
30 "Atque, ne tanquam sola deficiat custodienda commendatur praescripto Lucensi episcopo sancto Anselmo, commendatur, inquam, omni diligentia et affectu charitatis, commendatur a beatissimo magistro fidelissimo discipulo, sicut in cruce Christus matrem virginem virgini discipulo commendavit: Mater, inquiens, ecce filius tuus; ad discipulum autem: Ecce mater tua $[\ldots] »:$ Vita Anselmi, c. 12, 17.

31 "Gregorius presul Romanus, ut egit Iesus In cruce qui moriens dat discipulo genitricem, Commisit dominam sic Anselmo comitissam»: Vita Mathildis, 2, vv. 284-286, 385.
} 
of all Christianity [Ropa 1979, 25-51]. In this way, Gregory entrusts to Matilda the defense of the Church and of the Christians.

My argument will be that the new role and prominence of the Virgin introduced by Anselm II in his Prayers was mainly inspired by the life of the countess. Matilda, like the Virgin, had an active role in history, effected by her "yes» to God (in the person of Gregory VII), by which she saved the world from evil. Matilda's crucial roles of intercessor, protector of all persecuted Christians, and tireless defender of the church, was indeed comparable to Mary's roles as intercessor, protector, and loving mother. Indeed, Anselm mentions the above-cited passage of the Gospel of John three times in his Prayers for Matilda, where he describes the Virgin as a mother and Christians as «adopted children». As Silvia Cantelli and André Wilmart argue, Anselm wrote three of the Prayers to prepare Matilda's soul to receive Holy Communion, and the other two to foster the countess's devotion to the Virgin Mary, in a faithful response to the pope's indications. ${ }^{32}$ In a letter dated 1074, the pope urges Matilda: "You should frequently receive the Lord's body, and I have directed that you should wholly commit yourself to sure confidence in the Mother of the Lord $[\ldots]{ }^{3}{ }^{33}$ In the first prayer for communion, Anselm, in a unique way, encourages Matilda, the devout reader, to become one with the Virgin; through an exercise of identification, Anselm leads Matilda through the most important events in the life of Mary. Matilda is placed in Mary's room at the moment of the Angel's annunciation: "I like to see with the eye of the soul the angel Gabriel proffering his most kind greeting and announcing to you the forthcoming of the Holy Infant; [I like] to hear the admirable response of your humility».34 Similarly, Matilda is present during the nativity:

Wilmart 1938, 28; Cantelli 1987, 290-299.

Gregory VII, Registrum, I, 47, in Cowdrey 2002, 51-53.

"Delectat me videre interior oculo Gabrielem angelum te officiosissime salutantem et santum nasciturum annuntiatem, audire admirabile responsum tue humilitatis, Oratio vene- 
«[I like to admire] the first manifestations of the baby [...] lying in a manger». ${ }^{35}$ Anselm, through this prayer, expresses his astonishment and veneration in front of God, the unfathomable mystery, who decided to become a man in the womb of a woman and submit to human laws and needs. ${ }^{36}$ Matilda, the reader, is also led to admire Mary's affectionate intervention during the wedding of Cana. Anselm then leads her to the scene of Calvary, in which Jesus addresses his mother for the last time, commending her to John and the disciple to her: "Jesus recommended his blessed mother to his disciple and his disciple to his mother - Mary, he says, here is your son; apostle, here is your mother». ${ }^{37}$ According to Anselm, it is precisely in this moment that Mary was entrusted with the protection of all Christians. Cantelli explains, referring to this passage, that it is the first time in the Christian tradition in which the spiritual maternity of Mary is associated with Calvary. Because of this innovation, Fulton describes Anselm's Prayers: as "one of the most important eleventh-century contributions to subsequent Marian doctrine", [Fulton 2002, 225]. In the third prayer to the Virgin Mary, Matilda is again present at the Annunciation, at the loss of the boy Jesus in the temple, at the Crucifixion, and at the Assumption. Also in this prayer, the moment of Calvary takes on a special meaning: "[Mary] adopted us as children $[\ldots]$ She inclines to indulgence toward us with the love of a mother, which surpasses in richness and sensitivity any other human feeling».38 In this prayer Matilda is even more intensely involved

rabilis Anselmi): in Wilmart 1938, 51-52.

${ }_{35} \quad$ "Libet admirari] paruli rudimenta [...] in presepio iacentem, Oratio venerabilis Anselmi»: Wilmart 1938, 51-52.

${ }_{36}$ «[...] in nostra natura divinitatis potentiam, Oratio venerabilis Anselmi»: Wilmart 1938, 51-52.

37 «Oratio venerabilis Anselmi»: Wilmart 1938, 53.

38 «[..] subrogavit nos in filios [...] ut tanto proclivior fieret ad indulgentiam quanto materne caritatis viscera super omnemcarnis affectum habundantia pietatis exuberant, Oratio Venerabilis Anselmi Episcopi ad Santcta Mariam»: Wilmart 1938, 63-64. 
in Calvary than in the first one - under the cross of Jesus, Matilda takes part in Mary's and John's suffering for the redemption of humanity: "sharing your immense suffering». ${ }^{39}$ Matilda could feel what Mary felt. Anselm's prayers have an element of novelty in respect to the tradition of his time [Cantelli 1987, 294-295; Fulton 2002, 195-243]: Christ is no longer the triumphant and distant God of the Last Judgment; on the contrary, he is perceived as the tender baby of the nativity. The image of Mary, as envisioned by Anselm, is no longer the detached Queen of Heaven but a grieving and affectionate mother.

What was it that enabled Anselm to develop this unique conception of Mary? The novelty of Anselm's devotion is in his understanding of the motherhood of Mary, a concept that appears to have been suggested by the life and personality of the countess. Certainly, Matilda had a very important role as mediator during the controversies between emperor and pope, and, as Donizo writes, she became the protector of all persecuted Christians:

Only Matilda's spacious home was pure./This [home] was truly a safe place, a harbor for believers:/The ones that the king condemned, expelled or stripped/bishops, monks, clerics, Italians and even French people/ They all ran, confident, to the living fountain,/To the Lady of benevolent mind./They found near her all they were longing for $[\ldots] .^{40}$

Indeed, because Gregory commended to Matilda the leadership of Christians, Anselm compared Mary's mission to Matilda's. The spiritual closeness to Mary to which the countess was called, developed through these prayers, enabled her to become one with the Virgin Mary. Matil-

\footnotetext{
39 "[...] compaciens immenso dolori consoler te donec, Oratio Venerabilis Anselmi Episcopi ad Santcta Mariam»: Wilmart 1938, 63-64.

40 «Munda domus sola Mathildis erat spaciosa./Catholicis prorsus fuit haec tutus quasi portus:/Nam quos dampnabat rex, pellebat, spoliabat/Pontefices, monachos, clericos, Italos quoque Gallos,/Ad vivum fontem currebant funditus omnes,/Scilicet ad dictam dominam iam, mente benignam./ Quaeque requirebant, apud ipsam repperiebant [...]»: Vita Mathildis, 2, vv. 269-275, 385.
} 
da was seen by Anselm as the living embodiment of the Virgin in the way she lived out her life. Anselm, with these Prayers, instructed her to live according to this image.

\section{Come, my Bride, my Beloved, my Dove - Matilda Bride of God}

The important parallel Anselm established between Mary and Matilda is also supported by the numerous references to the Biblical Song of Songs in Anselm's Prayers." Anselm uses the term sponsa, to denote the bride Matilda:

You will introduce me in my groom's chamber, bringing me with you [Mary], you will show me the One, whom my soul yearned for and I will deserve to hear His beloved voice that will say: Come, my bride, my beloved, my dove; he will kiss me with the kiss of His mouth, and I will be full of grace, [I will be] imbued with sweetness. ${ }^{42}$

This passage of the Song of Songs was the source of the eleventh century tradition for the liturgy of the feast of the Assumption, in which the Virgin Mary is «transformed» from mother to bride. I relied on Fulton's investigation for the tradition and liturgy of the feast of Assumption in the eleventh century; however, she does not connect this tradition and liturgy with Anselm's Prayers for Matilda [Fulton 2002, 244-288]. This passage was read as a dialogue between the Virgin and Christ and the words veni sponsa were, according to this tradition, pronounced by Christ as he came to lead his mother into heaven [Fulton 2008, 195243; 2009]. Anselm introduced the term sponsa Dei in order to foster

\footnotetext{
${ }^{41}$ Song of Songs, 1, 3; 2, 8; 5.

42 «In cubiculum sponsi mei, post te trahens, introducas et ostendas mihi quem concupivit anima mea, ut desideratam vocem ejus audire merear. Veni sponsa mea, dilecta mea, columba mea, et osculetur me osculo oris sui, gratia plena, suavitate inclita, Oratio venerabilis Anselmi»: Wilmart 1938, 54; refers to, Song of Songs, 1, 3.
} 
Matilda's identification with the Virgin. ${ }^{43}$ This term later became, not by chance, a common appellative given to Matilda [Ropa 1979, 25-51; Maccarini 1979, 53-66]:

But since evil was increasing, [Matilda] is forced to defend the church, and welcome Anselm as a counselor and teacher, who, as a guide, can teach her the sacred ways and, as a groomsman of Christ the Lord, can show her the honors and richness of the father, and enabling [her] to convert human love into divine love, to adorn the matrimonial bed and the bridal chamber with flowers, and watchful he can teach her to keep the lamp lit, until the coming of the groom who will welcome her for himself. ${ }^{45}$

Matilda is presented as a privileged bride willing to give her whole soul to her groom, God. It is evident that these images used to describe Matilda were inspired by Anselm's descriptions in his Prayers. Anselm is defined as her counselor (monitorem) and teacher (magistrum), and he is also the "groomsman" of Christ, the one who accompanies the bride into the chamber of the groom, a metaphor of conjugal love, which describes the relationship between Matilda and Christ as the personification of the relationship between Mary and Christ.

This kind of "political allegory", i.e., the interpretation of the Scriptures by referring to current political events and by associating their protagonists with scriptural characters, originated precisely with the polemicists of the Gregorian reform. The evidence that Anselm adopted this

The term «bride of Christ» was also used often as metaphor of the Church, see McLaughlin 2010, 51-91.

${ }^{44}$ John of Mantua in his In Cantica Canticorum et de Sancta Maria Tractatus ad Comitissam Mathildam.

45 «Sed iam iamque malis increbrescentibus istis/ Ad deffendendam cogitur aecclesiam./ Suscipit Anselmum monitorem sive magistrum,/ Qui doceat sacras signifier ipse vias/ Et Christy Domini tanquam paranimphus honores/Illius exponat diviciasque patris/Atque in languorem sanctum convertat amorem,/ Exornet talamum floribus atque thorum, / Pervigil accensam doceat servare lucernam,/ Dum sponsus veniat, qui sibi suscipiat./»: Vita Metrica, vv. 3565-3574, 1232. 
method is also provided by his commentaries, which were commissioned by Matilda. Indeed, in Anselm's commentary to the Psalter [II.2-3], he compared Gregory VII to Jesus, Henry to Pilate, and the anti-pope Clement III to Barabbas; his commentary on Matthew's Cleansing of the Temple is an expression of the political program of the Gregorian reform. ${ }^{46}$ The official biographers of Anselm and Matilda later renewed and expanded the comparison between Matilda's mission and Mary's but their intent was more strictly eulogistic in the promotion of their patroness' loyalty to the pope and reform: they were composed at Matilda of Tuscany's court and commissioned by the countess. Her entourage became, in fact, a secure refuge for all those intellectuals, polemicists, monks, and clergy who were expelled or deposed by the king [Robinson 2004, 49-59; 1978, 100-103].

\section{Anselm and John the Evangelist}

Just as important as the comparison between Matilda and the Virgin Mary is the association of Anselm with the apostle John in Vita Ansel$m i$ and in Donizo's account. Because of John's unconditional love for Jesus, he was chosen by his master to be the guardian of Mary's life. Anselm's exceptional interpretation of the apostle John in his Prayers probably led Donizo and the unknown author of the Vita to associate Anselm with John, the personification of friendship and virginity.

Brian McGuire explains that in the eleventh and twelfth centuries John acquired a prominent role due to his exceptional friendship with Christ. Peter Damien celebrated John's virginity and offered it as the main explanation for his unique relationship with Christ; Anselm of Canter-

Anselm's commentary on the Psalter is in Paul of Bernried, Vita Gregorii VII, in Robinson 2004, 355-356; Matthew's commentary is published in Rough 1973, 3233. For "political allegory» see Robinson 1983, Cantelli 1985; Amari 2015; McLaughlin 2010, 6; Ropa G. 1979. 
bury used the evangelist as the highest example of friendship; and finally, Goscelin of St. Bertin portrayed John as Jesus' friend when, at the crucial moment on Calvary, the Lord, because of this companionship, entrusted his mother to him. McGuire suggests that this model of love could have been one of the factors that fostered a generally increased interest in friendship during this period [McGuire 1988, xxviii, 208209, 219-220]. John is an example of friendship and unconditional love and at the same time the paradigm of purity and chastity. According to the anonymous author of Vita Anselmi, Anselm's life and extraordinary relationship with Gregory VII summarized perfectly two characteristics attributed to John: "virginity» and «discipleship». These two themes were the most urgent concerns of the Gregorian reform at that moment. Regarding «discipleship», Anselm was certainly, among the intellectuals at Matilda's court, the most influential disciple and the most rooted in the Gregorian tradition.

It is not a coincidence that in his Life of Gregory VII, Paul of Bernried introduces Anselm of Lucca in this way:

It seems appropriate to introduce here the foremost follower and heir of his [Gregory VII's] virtues, the blessed Anselm, bishop of the church of Lucca [...] Likewise when Gregory was about to depart from this mortal life, he sent to Anselm a symbol of papal power, namely the mitre from his head. ${ }^{47}$

Anselm was the pope's most faithful disciple - so much so that Gregory wanted to designate Anselm as his successor. ${ }^{48}$ Virginity, another characteristic attributed to Anselm, was the foundation of the Gregorian reform movement and therefore promoted during the Investiture Controversy as an attempt to renew the entire church according to monastic ideals. All of these reasons, and Anselm's extraordinary portrayal in his Prayers of the apostle John during the scene of Calvary,

Paul of Bernried, Vita Gregorii VII, in Robinson 2004, 354.

48 Vita Anselmi, c. 32, 22-23. 
probably led Donizo and the anonymous author of Vita Anselmi, to compare John to Anselm, establishing him as an example of friendship and virginity.

\section{Anselm's Novel Devotion and the Eucharistic Controversy}

As we have seen, Anselm of Lucca's encounter with Matilda and his obedience to Gregory VII allowed him to develop a new spiritual devotion to the Virgin in his Prayers. In order to fully understand the origin of this novelty, it is essential to consider Anselm's involvement with the Eucharistic Controversy. In this section, I will argue that Anselm's personal contribution to this debate is strongly reflected in his Prayers, in which he drew from Lanfranc's theology to express the notion of the power of the presence of God in the Host and the mystery of the Eucharistic phenomenon. According to Fulton, one of the historical reasons for this new elaboration of the devotion to Christ and the Virgin Mary may have been the profound impact that the Eucharistic Controversy had in the minds of scholars, the clergy, and the laity." The Eucharistic Controversy originated in the monasteries of northern France, and pitted Berengar of Tours, who questioned the real presence of the body of Christ in the Eucharist, against Lanfranc, abbot of Bec, who vehemently affirmed the real presence. Berengar's position and the polemic that it generated undermined the very nature of the Church itself and, as Fulton notes, inevitably forced new developments in the practices of devotion to Christ and the Virgin Mary. ${ }^{50}$ The controversy began in the middle of the eleventh century, was addressed in Rome for the first time by Leo IX, and received continuing attention

49 Fulton 2002, 60-141.

For the Eucharistic Controversy see: Fulton 2002, 118-141; Radding, Newton, 2003, 1-31; Cowdrey 2003, 59-74. 
from Nicholas II and Gregory VII. Anselm's attendance at the Lenten synod of 1079 in Rome, where Berengar was definitively defeated and condemned by Gregory VII, shows his involvement with the dispute [Radding, Newton 2003, 104].51 The dispute allows us to connect Anselm of Lucca, his personality and thought, to the broader cultural milieu of Bec, Lanfranc, and Anselm of Canterbury, and permits an understanding of a new and unexplored aspect of both his faith and his relationship with Matilda.

One important piece of evidence of Anselm's profound association with the debate is a passage of John of Mantua, of Matilda's entourage, in his work dedicated to the countess, Tractatus in Cantica Canticorum. While speaking about the illustrious men at Matilda's court, John compliments one of them in particular, whose name he prefers not to mention for fear and in reverence of his authority. The mysterious man, John says, rejected human glory, and most of all, helped to eradicate the Berengarian heresy:

Indeed, by you, there is someone whose name I am afraid to mention since he flees worldly glory, one who by means of his words, with the other holy bishops, a Catholic stronghold, destroyed the repugnant heresy of Berengar and brought back in the holy bosom of the Church the confessed author of that same heresy. ${ }^{52}$

The man's identity can be inferred from the description that, in the same paragraph, John provides about the special relationship this man had with Matilda: "He, who grieving with you the wounds of reli-

${ }^{51}$ Radding, Newton 2003, 1-31, Lanfranc of Bec would reject Berengar's convictions regarding sacramentum and res, arguing that the very flesh of Christ was present in the Host visibly and spiritually; Lanfranc, On the body and blood of the Lord, in Villancourt 2009.

52 "Apud te enim est, quem, quia mundi gloriam fugit, nominare timeo, qui Berengariam haeresim his sententiis repugnantem cum aliis sanctis episcopis catholico destruxit praesidio et eiusdem haeresis auctorem confessum sancte matris ecclesiae restauravit gremio, [...]»: Bischoff, Taeger 1973, 49. 
gion, always fought to the end the common struggle of the church».5 This statement suggests that the mysterious person might be Anselm of Lucca.

Anselm's refutation and assistance with the condemnation of the Eucharistic teaching of Berengar is evident in the five prayers, in which he reaffirms the fundamental principles of the Catholic faith. In the above-mentioned first prayer, written in order to prepare Matilda for the Holy Communion, Matilda, the reader, professes her faith by saying: «I believe indeed and I confess: this most sacred host has the nature and glory of your vivifying flesh».54 The same concept is expressed in the fifth prayer for communion, which is an impassioned dialogue between the reader and the Eucharist:

But who am I, to be willing to see you and touch you, and moreover, who am I to not flee the occasion of eating you? For I know, even though my eyes cannot see it, that you are the blessed body that the Virgin Mary has generated and carried with awe on her arms [...] and it is precisely you, and not another, that now I am not afraid to grab with my teeth and touch with my flesh of shame.5:

The recurrence of the words: «tangere», «videre», «dentibus», «conprehendere», and "caro» in the above passage emphasize and defend the idea of God's incarnation and the presence of the human God in reality, up to the point of being able to be seen and eaten. ${ }^{56}$ The prayer goes on

${ }_{53}$ "[...] qui tecum gemens religionis damma communem eccleasiae semper pertulit pugnam, John of Mantua, In Cantica canticorum»: Bischoff, Taeger 1973, 49.

54 "Credo enim et confiteor hanc sacratissimam hostiam vivifice carnis tue naturam habere et gloriam, Oratio venerabilis Anselmi»: Wilmart 1938, 56.

«Sed ego, que sum que te tallem videre et tangere, eciam manducare non fugio? Scio enim, licet oculi mei teneantur ne te sicut es videam, quod es illa benedicta caro quam genuit et reverenter baiullavit virgo Maria... Te ipsum portare, te ipsum, et non allium, nunc dentibus conprehendere et carne turpitudinis tangere non aborreo, Oratio Beati Anselmi ad Corpus Christi»: Wilmart 1938, 70.

56 This notion is also in Lanfranc, On the body and blood of the Lord, in Villancourt 2009, 52-64. 
to say that it is because of our sin that we are not able to perceive this wondrous event in our life: "Wondrous change! The soul is less than the body. The body sees you; the soul is blind. The body can touch you; the soul, which is made in your own image, is alien to you». ${ }^{57}$ The primary issue for Lanfranc of Bec and also for Anselm was to recognize the mysterious event of transubstantiation, not with reason and intellect but with faith. ${ }^{58}$ This, according to Anselm, was the only way to access God's presence in this life. Denying this principal truth meant, for Anselm, denying the entire Church: "If I don't believe, I have to deny the whole church, on earth and in Heaven, and I have to deny even You, the very essence of Truth».59 Anselm's remedy for the sinful state of the soul is an appeal to the Virgin. Indeed, the body of Christ, was conceived in the womb of Mary; she first touched him, saw him:

But I believe and I know and I am certain of you that - I see with the eyes of my flesh, which are impeded to receive the truth - You are the one that the Virgin, even if she was his mother, never touched without reverence, never perceived without magnificence, never thought about you without joyful exultation. ${ }^{60}$

Mary gave birth to Jesus, and for this reason, she was the way through which humanity could recover a true relationship with God. ${ }^{61}$ This is

\footnotetext{
${ }^{57}$ "Mirabilis commutatio. Inferrior est corpore anima. Corpus te videt; anima ceca est. Corpus te tangit; mens, similis tibi, a te aliena existit, Oratio Beati Anselmi ad Corpus Christi»: Wilmart 1938, 71.

58 Radding, Newton, 2003, 35-85; Lanfranc, On the body and blood of the Lord, in Villancourt 2009, 30-35.

59 «Si non credo, toti ecclesie in celo et in terra ipsique tibi, qui es veritas per essentiam, contradico, Oratio Beati Anselmi ad Corpus Christi»: Wilmart 1938, 71.
}

60 «Sed credo et scio, et certa sum de te, - quem corporeis ocullis, licet ad veritatem impeditis, video, - quod es ille quem virgo, licet mater, nunquam tetigit sine reverential, nenquam sensit sine magnificentia, nunquam de eo cogitavit sine exultation iocunda, Oratio Beati Anselmi ad Corpus Christi»: Wilmart 1938, 71.

${ }_{61}$ The same concept is expressed by Lanfranc in, On the body and blood of the Lord, in Villancourt 2009, 66-71. 
also the reason why Anselm insists that Matilda have a passionate determination to become one with the Virgin Mary, who first had the privilege to touch, nurture, clothe, and love the human God. The purpose of the prayers is to make the reader see and feel the same things the Virgin felt, in order to experience God in the flesh.

The prayers demonstrate that Anselm's piety was familiar with Lanfranc's ideas and the new spiritual developments emerging from the Anglo-Norman world. This specific cultural setting induced the bishop of Lucca to seek new approaches to devotion to Christ and the Virgin Mary. At the same time, for Anselm, the reception of these new spiritual ideals was facilitated by his encounter with Matilda. This encounter led him to elaborate these concepts in a personal and different way. Indeed, the most remarkable aspect of Anselm's Prayers is the fact that they appear to have been written specifically for the life, personality, and role in history of Matilda of Tuscany.

\section{The Meaning of Friendship}

The mystery of the Incarnation and the new attention toward the humanity of God is at the origin of a new concept of friendship as well. This new spiritual idea stems from the perception that if God became a man, our relationship with God coincides with our relationship with a companionship of brothers and sisters who share the desire to experience and follow Him in every aspect of reality. The new value placed on friendship by men and women of the eleventh and twelfth centuries is another aspect of the novel devotions to Christ and the Virgin. A completely new way of expressing friendship is attested to in Northern Europe by the copious letters, prayers, and vitae from this period, which are the evidence of a spiritual friendship between men and women as a means of leading their brothers and sisters closer to Christ. The medieval writers who renewed and revitalized the idea of frien- 
dship looked to the classical tradition as well as the Bible. A definition by Gregory the Great, which McGuire records in his book, Friendship and Community, ${ }^{62}$ perfectly summarized the meaning and scope of this rediscovered friendship and perfectly applies to the relationship between Matilda and Anselm. ${ }^{63}$ By this definition, a friend is a custos animi, responsible for his friend's happiness and salvation [McGuire 1988, xv]. In addition, the life and works of a few spiritual men like Goscelin of St. Bertin [Otter 2004], the unknown author of The Life of Christina of Markyate [Fanous, Leyser 2008], and the great innovator Anselm of Canterbury [Vaughn 2002], illustrate an increased attention to spiritual relationships with women. Remarkably, some of these women were both politically very influential and devoted to God, and hence able to act, at times, as teachers for their male friends. These new ideas were promoted and enhanced in the cultural milieu of the Anglo-Norman world; the description of the friendship between Anselm and Matilda shares many themes, images, and rhetorical features in common with the ideals mentioned above. However, while normally a woman entrusted her soul to a wise and authoritative teacher, the friendship between Anselm and Matilda originated from their common obedience to Pope Gregory VII. The pope commended Matilda to Anselm as a guide for her life, both for her spiritual and temporal affairs. This fact placed the union of the two participants in a privileged position because they both believed the union was willed by God in order to fulfill his purposes. Indeed, the main focus of the relationship between Anselm and Matilda was to love God and the Church. As attested by Rangerius in the passage already discussed above, the groomsman Anselm enabled Matilda to

\footnotetext{
In McGuire 1988, the author locates the fundamental aspects of friendship only within the monastic world, seeing friendship as something that was practiced and developed predominantly within relationships between men.

${ }_{63}$ See also Canatella 2010, where the author argues that this spiritual friendship can be enjoyed by both men and women.
} 
convert human love into divine love. ${ }^{64}$ It is worth noting another passage from Rangerius that identifies Anselm as the cause of the countess's spiritual growth:

Often [Matilda] associates with Anselm, she hangs on every word he says/ and diligently she serves him as a lord./She never fails to attend to Anselm's office at night or during the day, and she prays when he prays, weeps when he weeps and suffers when he suffers; she takes the shape of the disciple and of the servant..$^{65}$

The relationship between master and disciple usually involved an imbalance of power between them [Vaughn, Rubenstein 2006, 1-18; Tinsley 2010, 477-482], as we have seen, the friendship between Anselm and Matilda was based on obedience. Vita Anselmi insists that the bishop of Lucca was far from being only Matilda's spiritual advisor; on the contrary, the anonymous author declares that Anselm was the leader and the mind behind her government: "[Matilda] was inspired by a mother's piety, $[\ldots]$ he practiced the art of governing; she wielded power, $[\ldots]$ he ruled; she issued orders and he gave counsel».66

Yet, reciprocal support was also an important aspect of their relationship. Matilda is often both a guide for and a disciple of Anselm. When Anselm regretted his imperial obedience, before taking his place as bishop in Lucca, he faced a painful crisis which eventually led him to withdraw from the world. Both Vitae describe this episode. In Vita Anselmi, the anonymous author highlights the secret nature of his decision: «[Anselm], without informing family and friends, became a monk

${ }_{64}$ For this notion see: Vaughn, Rubenstein 2006, 1-18; McGuire 1988, 180-230; Classen, Sandidge 2010.

${ }_{65}$ «Anselmum celebrat, Anselmi pendet ab ore/Et tamquam domino sedula servit ei./Eius ab officio nocturne sive diurno/Numquam discedit cumque legente legit; Ploranti applorat et cum patiente laborat, Formam discipulae suscipit et famulae»: Vita Metrica, vv. 3687-3692, 1234.

66 «Illa pro pietate matris solicitabatur, ille gubernandi artem meditabatur; illa potestatem exercebat, ille regebat; illa praeceptum et ille dedit consilium»: Vita Anselmi, c. 20, 19. 
according to the rule of St. Benedict». ${ }^{67}$ Interestingly, Bishop Rangerius in Vita Metrica informs the reader not only about Matilda's knowledge of Anselm's decision but also describes her reaction. Rangerius uses this episode to introduce Matilda for the first time in the poem and qualifies her as: "The sacred servant of the sacred religion...the terror of perfidy, defender of the faith, and solicitous nurturer of the pious pontiffs». ${ }^{68} \mathrm{In}$ the dialogue that follows Matilda beseeches Anselm not to leave the city and herself sine patre ${ }^{69}$ in the midst of dangerous threats. Moreover, the countess comforts Anselm over the sin he committed and exhorts him not to abandon his people. She asks him to follow the example of St. Peter, who, even though he also betrayed the Lord, was entrusted with the keys of Heaven. ${ }^{70}$ In this case, Matilda acts as the mulier fortis, ${ }^{71}$ invested with the responsibility for showing Anselm the correct path. This moving dialogue illuminates a special aspect of their relationship: reciprocal support during difficult times [Tinsley 2010, 477-500]. This reciprocal support and harmony between Matilda and Anselm was also the supreme example of the ideal relationship, in both the private and the public spheres, between regnum and sacerdotium [Pasztor 1964]. Certainly, spiritual friendship and political ideals could be associated. For Gregory VII the apex of caritas was to serve the Church and its mission in the active life. Matilda followed this principle, and, according to her biographer and to the intellectuals in her entourage, was

\footnotetext{
${ }^{67}$ "[...] et nescientibus qui cum ipso erant parentibus ac fidelibus, fit subito monachus, regulae sancti Benedicti et Cluniacensium consuetudini subiectus»: Vita Anselmi, c. 4, 14.

68 «Sacrae sacra vernula religionis, Perfidiae terror, subsidium fidei, sedula pontificum nutrix...piorum»: Vita Metrica, vv. 953-955, 1177.

69 Vita Metrica, vv. 957, 1177.

70 Matilda's monologue: Vita Metrica, vv. 953-996, 1177-1178.

Vita Metrica, v. 3700; the passage, Vita Metrica 3699-3954, is an exegesis of the Proverbs, 31:10-31, in which Rangerius describes Matilda as Sponsa Dei and Mulier fortis; for more details on these concepts see: Amari 2015, 9; Ropa 1979, 25-51; Maccarini 1979, 53-66.
} 
ready to sacrifice her worldly goods, her power, and even her life for the triumph of righteousness.

Furthermore, despite her defeat in the battle of Volta Mantovana, in which she was forced to retreat to her hidden castles in the Apennines, Matilda continued to defend the pope and the Church. Because of this resistance, the Henrician polemicists accused the countess of being brainwashed by the Gregorian ideas concerning Christian warfare. The imperial polemicist Benzo of Alba, in his work, To Emperor Henry IV, blamed Anselm and Matilda for having "stripped $»^{72}$ the monasteries of Nonantola and St. Apollonio in order to wage war against the emperor. ${ }^{73}$ However, the most influential polemicist among the emperor's circle was Wibert of Ravenna, who accused Anselm of deceiving Matilda with the false promise of eternal life. ${ }^{74}$ The bishop of Lucca's written response, in the Book against Wibert, ${ }^{75}$ explains not only the very nature and purpose of his relationship with Matilda but also its correspondence with the will of God and the Church's mission:

[...] you [Wibert] beseech me in Jesus' name, no longer to deceive, delude and dupe the most noble of women; but I call on God as my witness that there is nothing in her earthly or carnal nor do I desire suchlike from her [...] by protecting her I am serving, day and night, my God and my holy mother church, by whose order she was entrusted to me. ${ }^{76}$

72 «Facie exterminati nudant»: Benzo of Alba, Ad Heinricum IV, 663; Anselm and Matilda donated the treasure's monasteries to the pope, who was surrounded by the king's troops in Rome: Ghirardini 1987, 239.

73 For more details, see Benzo of Alba, Ad Heinricum IV, 663; Vita Mathildis, 2, vv. 302-303, 385; Ghirardini 1987, 239.

${ }_{74}$ This record, written by Wibert of Ravenna to Anselm of Lucca, is lost; however, as Robinson explains $(2004,46)$, the anti-pope's arguments can be deduced by Anselm's response to him in Book against Wibert, which was written for the purpose of confuting Wibert's accusations.

75 Anselm II of Lucca, Liber contra Wibertum.

76 "Quod autem obsecras per Iesum, ne nobilissimam feminarum amplius circumveniam , deludam, et fallam, Deum testem invoco, nihil terrenum, nihilque carnale in ea vel ab ea ex intentione concupisco, et sine intermissione oro ut ab hoc seculo nequam cito eripi me 
Anselm explains that Matilda's choice to remain at the pope's side was not unconsidered or irrational, but was rather a heroic act of faith:

[...] she does not, as you claim, waste her possessions in vain, but rather lays up for herself an unfailing treasure in heaven, where, neither thieves nor burglars steal; she is prepared not only to sacrifice all earthly considerations for the sake of defending righteousness, but also to struggle even to the shedding of her own blood to bring about your confusion and for the sake of reverence for the glory and exaltation of holy church, until the Lord delivers His enemy into the hands of a woman.?

This passage clarifies the nature and the goal of this friendship in Anselm's own words. According to the bishop of Lucca, the church handed over to him the responsibility of instructing the life of Countess Matilda in both spiritual and temporal matters. This commendation bestowed on their union a special mission they believed to have been willed by God, inevitably forcing them to solemnly think about themselves and their roles in new ways.

\section{Conclusion}

The sources define the friendship between Anselm and Matilda as originating in their obedience to Pope Gregory VII. Certainly, Anselm of Lucca was one of the most loyal partisans of the pope and the most rooted in the Gregorian tradition, but his intellectual development was not only the product of the cultural milieu of the Italian reform movement; on the contrary, his education was also influenced by the new intellec-

rear, nimio affectus taedio, quia incolatum meum prolongari video, serviens die ac nocte in custodiendo illam Deo meo, et sanctae matri meae ecclesiae, cuius praecepto mihi com missa est, et spero quod multa mihi retributio per gratiam Dei in eius custodia excrescat»: Anselm II of Lucca, Liber contra Wibertum, 527.

Anselm II of Lucca, Liber contra Wibertum, translation in Robinson 2004, 46-47. 
tual ideas emanating from northern Europe connected with Anselm of Canterbury, Lanfranc, and the school of Bec.

Indeed, new ways of practicing devotion to Christ and his suffering, and the attention paid to and the discovery of the fundamental role of his compassionate and grieving mother, were first developed in the monasteries of northern Europe over the course of the eleventh century. These developments were triggered by the Eucharistic Controversy and reached their apex with the spirituality of Anselm of Canterbury. The most striking evidence of Anselm of Lucca's reception of these new ideas is reflected in his Prayers, which reveal not only a new aspect of Anselm and Matilda's relationship but also the bishop's way of conceiving of the historical presence of God. In these Prayers, Mary is a compassionate mother, truly concerned with the salvation of all her adopted children, and Anselm's encounter with Matilda allowed him to absorb and elaborate in a personal way the new spiritual concepts. Anselm's human description of the Virgin Mary and her loving mission was designed specifically for Matilda, who Anselm saw as a living embodiment of God's mother and bride. Anselm instructed Matilda to live according to this image, and he taught her to think about herself as sponsa Dei, bride of Christ. Matilda embraced these ideals and dedicated herself to the defense of the Church and of Christians. Furthermore, she fostered the development of these concepts, commissioning the biographies and other works, that prolonged and expanded Anselm's vision.

The new attention toward the humanity of God is at the origin of a new concept of friendship as well. As the authors of the first vitae remind us, the pope commended Anselm as Matilda's guide in both spiritual and temporal affairs. They describe the relationship as structured according to the medieval principle of friendship between master and disciple, first attested to in Northern Europe. However, the authors of the vitae saw the relationship between Anselm and the countess as unique. This uniqueness was embodied by the fact that their friendship was believed to have been willed by God Himself to fulfill His mission 
on earth. God, for these friends, was no longer distant; on the contrary, He was present in reality in the person of the pope, the living embodiment of Christ; in His faithful disciple, Anselm of Lucca; and in His loving mother, Countess Matilda of Tuscany. These re-presentations are the catalyst and the origin of the active involvement of Anselm and Matilda with the reality of their time.

\section{Bibliography}

\section{Primary sources}

Anselm II of Lucca, Liber contra Wibertum, Bernheim E. (ed.), Monumenta Germaniae Historica, Libelli de Lite imperatorum et pontificum, 1, Hannover, 1891, 517-528.

- Letter to William I of England, Erdmann C., Fickermann N. (ed), Monumenta Germaniae Historica, Epistolae [Briefe], Briefsammlungen der Zeit Heinrichs IV, 5, Hannover, 1950, 15-17.

Benzo of Alba, Ad Heinricum IV, imperatorem libri VII, Pertz G. H. (ed), Monumenta Germaniae Historica, Scriptores (in Folio), 11, Hannover, 1854, 591-681.

Bonizo of Sutri, Liber ad amicum, Dümmler E. (ed.), Monumenta Germaniae Historica, Libelli de Lite imperatorum et pontificum, 1, Hannover, 1891, 568-690.

Donizo of Canossa, Vita Mathildis, Bethmann L. (ed.), Monumenta Germaniae Historica, Scriptores (in Folio) 12, Hannover, 1856, 348-409.

Gregory VII, Registrum, Caspar E. (ed.), Monumenta Germaniae Historica, Epistolae Selectae 2, Berlin, 1920-1923.

Hugh of Flavigny, Chronicon, Pertz G. H. (ed), Monumenta Germaniae Historica, Scriptores (in Folio), 8, Hannover, 1848, 288-502.

Rangerius of Lucca, Vita metrica sancti Anselmi Lucensis episcopi, Hofmeister A. (ed.), Monumenta Germaniae Historica, Scriptores (in Folio), 30/2, Lipsia, 1934, 11521307.

Vita Anselmi episcopi Lucensis, Wilmans R. (ed.), Monumenta Germaniae Historica, Scriptores (in Folio), 12, Hannover, 1856 13-35. 


\section{Edition of primary sources}

Amari R. (ed.) 2015, Rangerio. Il poema di Anselmo, vescovo di Lucca, Pisa: Pisa University Press.

Bischoff B., Taeger B. (eds.) 1973, John of Mantua In Cantica canticorum et de Sancta Maria tractatus ad comitissam Matildam, Freiburg: Universitatsverlag.

Cowdrey H. E. J. (ed.) 1972, The Epistolae vagantes of Pope Gregory VII, Oxford: Clarendon Press.

- 2002, The register of Pope Gregory VII, 1073-1085: an English translation, Oxford: Oxford University Press.

Golinelli P. (ed.) 2008, Donizone, Vita di Matilde di Canossa, Milano: Jaca Book.

Fanous S., Leyser H. (eds.) 2008, The life of Christina of Markyate, Oxford: Oxford University Press.

Otter M. (ed.) 2004, Goscelin of St. Bertin: The book of encouragement and consolation, Woodbridge: Boydell \& Brewer.

Robinson I. S. (ed.) 2004, The papal reform of the eleventh century: Lives of Pope Leo IX and Pope Gregory VII, Manchester: Manchester University Press, (Translation of Bonizo of Sutri, Book to a Friend), 158-261.

Vaillancourt M. G., (ed) 2009, Lanfranc, On the body and blood of the Lord, Washington: Catholic University of America Press.

Wilmart A. (ed.) 1938, Cinq Textes De Prière Composés Par Anselm De Lucques Pour La Comtesse Mathilde, "Revue d'ascétique et de mystique», 19, 23-72.

\section{Secondary sources}

Andreolli B. 1987, La gestione delle res ecclesiae nel territorio mantovano al tempo della lotta per le investiture, in Golinelli P. (ed.) 1987, Sant'Anselmo, Mantova e la lotta per le investiture: Atti del convegno internazionale di studi (Mantova, 23-24-25 maggio 1986), Bologna: Pàtron, 195-205.

Anton H. H. 1987, Primi stadi della riforma ecclesiastica: tendenze e valutazioni, in Golinelli P. (ed.) 1987, Sant'Anselmo, Mantova e la lotta per le investiture: Atti del convegno internazionale di studi (Mantova, 23-24-25 maggio 1986). Bologna: Pàtron, 269-279.

Bartolini M. G. 1965, Beatrice di Lorena, marchesa e duchessa di Toscana, in Dizionario Biografico degli Italiani, vol. 7, Roma: Istituto della Enciclopedia Italiana, 352-363.

- 1970, Bonifacio, marchese e duca di Toscana, in Dizionario Biografico degli Italiani, vol. 12, Roma: Istituto della Enciclopedia Italiana, 108.

Blumenthal U. R. R. 1988, The investiture controversy: Church and monarchy from the ninth to the twelfth century, Philadelphia: University of Pennsylvania Press. 
Borino G. B. 1956, Il Monacato e l'investitura di Anselmo vescovo di Lucca, in Borino G. B. (ed.) 1956, Studi gregoriani per la storia di Gregorio VII e della riforma gregoriana, vol. 5, Roma: Abbazia di san Paolo, 361-374.

Brunelli R. 2008, Anselmo di Lucca: consigliere di Matilde, patrono di Mantova, Mantova: Postumia.

Canatella H. 2010, Scripsit amica manus: Male-female spiritual friendship in England and France ca. 1050-1200, Ph.D. Dissertation, University of Houston.

Cantelli S. 1985, Il Commentario al Cantico dei Cantici di Giovanni da Mantova, "Studi medievali», 3 (26): 101-184.

- 1987, Le preghiere a Maria di Anselmo da Lucca, in Golinelli P. (ed.) 1987, Sant'Anselmo, Mantova e la lotta per le investiture: Atti del convegno internazionale di studi (Mantova, 23-24-25 maggio 1986), Bologna: Pàtron, 290-299.

Classen A., Sandidge M. (ed.) 2010, Friendship in the Middle Ages and early modern age: Explorations of a fundamental ethical discourse, Berlin: Walter de Gruyter.

Cowdrey H. E. J. 1972, Anselm of Besate and Some North-Italian Scholars of the Eleventh Century, "The Journal of Ecclesiastical History», 23, 2: 115-124.

- 1998, Pope Gregory VII, 1073-1085, Oxford: Clarendon Press.

- 2003, Lanfranc: Scholar, monk, and archbishop, Oxford: Oxford University Press.

Cushing K. G. 1998, Papacy and law in the Gregorian revolution: The canonistic work of Anselm of Lucca, Oxford: Clarendon Press.

D'Acunto N. 1999, I laici nella chiesa e nella società secondo Pier Damiani: Ceti dominanti e riforma ecclesiastica nel secolo XI, Roma: Istituto storico italiano per il Medio Evo.

Duff N. 1909, Matilda of Tuscany: La Gran Donna d'Italia, London: Methuen.

Eads V. 2000, Mighty in war: The role of Matilda of Tuscany in the war between Pope Gregory VII and Emperor Henry IV, Ph.D. Dissertation, City University of New York.

Fiorentini F. M., Mansi G. D. (eds.) 1756, Memorie della gran contessa Matilda restituita alla patria lucchese, da Francesco Maria Fiorentini. Seconda edizione illustrata con note critiche e con l'aggiunta di molti documenti appartenenti a Matilda ed alla di lei casa da Gian Domenico Mansi, Lucca: G. Batini.

Fonseca C. D. 1992, Il Capitolo di San Martino e la riforma canonicale nella seconda metà del secolo XI, in Violante C. (ed.) 1992, Sant'Anselmo vescovo di Lucca (1073-1086) nel quadro delle trasformazioni sociali e della riforma ecclesiastica, Atti del convegno internazionale di studio (Lucca 25-28 settembre 1986), Roma: Istituto Storico Italiano per il Medio Evo, 51-64.

Fumagalli V. 1971, Le origini di una grande dinastia feudale Adalberto-Atto di Canossa, Tübingen: M. Niemeyer. 
- 1984, Economia, società e istituzioni nei secoli XI-XII nel territorio modenese, in Barbolini M. A. (ed.) 1984, Lanfranco e Wiligelmo: Il Duomo di Modena, Modena: Panini, 7-12.

- 1984a, Il poema di Donizone nel Codice Vaticano Latino 4922, in Golinelli P. (ed.) 2008, Donizone, Vita di Matilde di Canossa, Milano: Jaca Book, 241-251.

- 1987, Mantova al tempo di Matilde di Canossa, 159-167, in Golinelli P. (ed.) 1987, Sant'Anselmo, Mantova e la lotta per le investiture: Atti del convegno internazionale di studi (Mantova, 23-24-25 maggio 1986), Bologna: Pàtron.

- 1996, Matilde di Canossa: Potenza e solitudine di una donna del Medioevo. Bologna: Il Mulino.

Fulton R. 2002, From judgment to passion: Devotion to Christ and the Virgin Mary, 8001200, New York: Columbia University Press.

- 2009, "Quae Est Ista Quae Ascendit Sicut Aurora Consurgens?”: The Song of Songs as the Historia for the Office of the Assumption", "Mediaeval Studies», 60 (1): 55-122.

Ghirardini L L. 1987, La Battaglia di Volta Mantovana, in Golinelli P. (ed.) 1987, Sant'Anselmo, Mantova e la lotta per le investiture: Atti del convegno internazionale di studi (Mantova, 23-24-25 maggio 1986). Bologna: Pàtron, 229-240.

Golinelli P. 1978, Culto dei santi e monasteri nella politica dei Canossa nella Pianura Padana, in Golinelli, P. (ed.) 1988, Indiscreta sanctitas: Studi sui rapporti tra culti, poteri e società nel pieno Medioevo, Roma: Istituto storico italiano per il Medio Evo, 9-29.

- 1984, Cultura e religiosità a Modena e Nonantola nell'alto e pieno Medioevo, in Barbolini M. A. (ed.) 1984, Lanfranco e Wiligelmo: Il Duomo di Modena, Modena: Panini.

- 1987, Dall'agiografia alla storia: le "Vitae” di Sant'Anselmo di Lucca, in Golinelli P. (ed.) 1987, Sant'Anselmo, Mantova e la lotta per le investiture: Atti del convegno internazionale di studi (Mantova, 23-24-25 maggio 1986). Bologna: Pàtron, 27-61.

- 1988, Una agiografia di lotta: le "Vitae" di Sant'Anselmo da Lucca, in Golinelli P. (ed.) 1988, Indiscreta sanctitas: Studi sui rapporti tra culti, poteri e società nel pieno Medioevo, Roma: Istituto storico italiano per il Medio Evo, 118-155.

- 1991, "Prima di Canossa. Considerazioni e notazioni sui rapporti di Gregorio VII con Beatrice e Matilde", in Stikler A. M. (ed.) 1991, Studi gregoriani. 14: Per la storia della Libertas ecclesiae. Roma: LAS, 195-206.

- (ed.) 1999, Matilde di Canossa nelle culture europee del secondo millennio: Dalla storia al mito: atti del convegno internazionale di studi (Reggio Emilia, Canossa, Quattro Castella, 25-27 settembre 1997), Bologna: Pàtron.

- 2003, I mille volti di Matilde: Immagini di un mito nei secoli, Milano: F. Motta.

- 2007, Matilde e i Canossa, Milano: Mursia.

- 2009, Matilde di Canossa, in Dizionario Biografico degli Italiani, vol. 72, Roma: Istituto dell'Enciclopedia Italiana, 114-126. 
- 2015, L'ancella di San Pietro: Matilde di Canossa e la Chiesa, Milano: Jaca Book.

Hay D. J. 2008, The military leadership of Matilda of Canossa, 1046-1115, Manchester: Manchester University Press.

Huddy M. E. 1906, Matilda, countess of Tuscany, London: John Long.

Keller H. 1992, Le origini sociali e famigliari del vescovo Anselmo, in Violante C. (ed.) 1992, Sant'Anselmo vescovo di Lucca (1073-1086) nel quadro delle trasformazioni sociali e della riforma ecclesiastica, Roma: Istituto Storico Italiano per il Medio Evo, 27-50.

Lazzari T. 2012, Goffredo di Lorena e Beatrice di Toscana, in Cantarella G. M., Calzona A. 2012, La reliquia del sangue di Cristo: Mantova, l'Italia e l'Europa al tempo di Leone IX, Verona: Scripta, 225-242.

Maccarini P. A. 1979, Aspetti della religiosità di Matilde di Canossa, in Badini G. (ed.) 1979, Convegno di studi matildici, Reggiolo medievale: Atti e memorie del Convegno di studi matildici: Reggiolo, 9 aprile 1978. Reggio Emilia: Bizzocchi, 53-66.

McGuire B. P. 1988, Friendship \& community: The monastic experience, 350-1250, Kalamazoo, Mich: Cistercian Publications.

McLaughlin M. 2010, Sex, gender, and episcopal authority in an age of reform, 1000-1122, Cambridge: Cambridge University Press.

Pasztor E. 1960, Una fonte per la storia dell'età gregoriana: la "Vita Anselmi episcopi Lucensis" in Bullettino dell'Istituto Storico Italiano per il Medioevo 1960, Bullettino 72. (1960), Roma: Palazzo Borromini, 1-33.

- 1964, Sacerdozio e Regno nella "Vita Anselmi Episcopi Lucensis", "Archivum Historiae Pontificiae», 2: 91-115.

- 1987, Lotta per le investiture e ius belli: la posizione di Anselmo di Lucca, in Golinelli, P. (ed.) 1987, Sant'Anselmo, Mantova e la lotta per le investiture: Atti del convegno internazionale di studi (Mantova, 23-24-25 maggio 1986), Bologna: Pàtron, 375-421.

- 1992, La "Vita" anonima di Anselmo da Lucca. Una rilettura, in Violante C. (ed.) 1992, Sant'Anselmo vescovo di Lucca (1073-1086) nel quadro delle trasformazioni sociali e della riforma ecclesiastica, Roma: Istituto Storico Italiano per il Medio Evo, 207-222.

Puglia A. 2013, Matilde di Canossa e le città della Toscana nord-occidentale tra XI e XII secolo, Pisa: Edizioni Il Campano, 11-39.

Radding C., Newton, F., Albericus, 2003, Theology, rhetoric, and politics in the Eucharistic controversy, 1078-1079: Alberic of Monte Cassino against Berengar of Tours, New York: Columbia University Press.

Robinson I. S. 2004, The papal reform of the eleventh century: Lives of Pope Leo IX and Pope Gregory VII, Manchester: Manchester University Press.

- 1983, 'Political Allegory' in the Biblical Exegesis of Bruno of Segni, «Recherches de théologie ancienne et médiévale», 1: 69-98. 
- 1978a, Authority and resistance in the Investiture Contest: The polemical literature of the late eleventh century, Manchester: Manchester University Press.

- 1978b, The friendship network of Gregory VII, «Journal of Ecclesiastical History», 63 (207): 1-22.

Ropa G. 1979, Intorno a un tema apologetico della letteratura "Matildica": Matilde di Canossa Dei Sponsa, in Badini G. (ed.) 1979, Convegno di studi matildici, Reggiolo medievale: Atti e memorie del Convegno di studi matildici: Reggiolo, 9 aprile 1978, Reggio Emilia: Bizzocchi, 25-51.

Rota A. 1733, Notizie istoriche di S. Anselmo, vescovo di Lucca, e protettore di Mantova, Verona: Per Pierantonio Berno librajo nella via de' Lioni.

Rough R. H. 1973, The Reformist Illumination in the Gospel of Matilda, Countess of Tuscany, The Hague: Nijhoff.

Saverino G. 1992, La "Vita Metrica" di Anselmo da Lucca scritta da Rangerio. Ideologia e genere letterario, in Violante C. (ed.) 1992, Sant'Anselmo vescovo di Lucca (10731086) nel quadro delle trasformazioni sociali e della riforma ecclesiastica, Roma: Istituto Storico Italiano per il Medio Evo, 223-272.

Sergi G. 1994, I poteri dei Canossa: poteri delegati, poteri feudali, poteri signorili, in Golinelli, P. (ed.) 1994, I Poteri dei Canossa, da Reggio Emilia all'Europa: Atti del convegno internazionale di studi (Reggio Emilia-Carpineti, 29-31 ottobre 1992), Bologna: Pàtron, 29-40.

Simeoni L. 1947, Il contributo della contessa Matilde al papato nella lotta per le investiture, in Borino G. B. (ed.) 1947, Studi Gregoriani per la storia di Gregorio VII e della riforma gregoriana, Roma: Abbazia di San Paolo, 353-372.

Spicciani A. 1992, L'episcopato lucchese di Anselmo II da Baggio, in Violante C. (ed.) 1992, Sant'Anselmo vescovo di Lucca (1073-1086) nel quadro delle trasformazioni sociali e della riforma ecclesiastica, Roma: Istituto Storico Italiano per il Medio Evo, 65-112.

Stickler A. 1947, Il potere coattivo materiale della Chiesa nella riforma gregoriana secondo Anselmo da Lucca, in Borino G. B. (ed.) 1947, «Studi Gregoriani», 1, Roma: 1947, 235-285.

Tinsley D. F. 2010, The Spiritual Friendship of Henry Suso and Elsbeth Stagel, in Classen A., Sandidge M. (eds.) 2010, Friendship in the Middle Ages and early modern age: Explorations of a fundamental ethical discourse, Berlin: Walter de Gruyter, 477-500.

Tosti L. 1859, La contessa Matilde e i romani pontefici, Firenze: Barbèra - Bianchi \& C. .

Vaughn S. N. 2002, St. Anselm and the handmaidens of God: A study of Anselm's correspondence with women, Turnhout: Brepols.

- 2010, Saint Anselm and His Students Writing about Love: A Theological Foundation for the Rise of Romantic Love in Europe, "Journal of the History of Sexuality», 19 (1): 54-73. 
Vaini M. 1987, Sant'Anselmo nella vita religiosa e culturale di Mantova nel basso Medioevo, in Golinelli P. (ed.) 1987, Sant'Anselmo, Mantova e la lotta per le investiture: Atti del convegno internazionale di studi (Mantova, 23-24-25 maggio 1986), Bologna: Pàtron, 63-79.

Vaughn S. N., Rubenstein, J. (eds.) 2006, Teaching and learning in Northern Europe, 1000-1200, Turnhout: Brepols.

Violante C. (ed.) 1992, Sant'Anselmo vescovo di Lucca (1073-1086) nel quadro delle trasformazioni sociali e della riforma ecclesiastica, Roma: Istituto Storico Italiano per il Medio Evo.

- 1961, Anselmo da Baggio, in Dizionario biografico degli Italiani, vol. 3, Roma: Istituto della Enciclopedia Italiana, 399-407. 